\title{
Streptozotosin ile İndüklenmiş Diyabetik Sıçanlarda Melatoninin Antioksidan Aktivitesi; Kan ve Karaciğer Dokusunda
}

\author{
Antioxidant Activity of Melatoninin in Streptozotocin-İnduced Diabetic Rats; \\ Blood and Liver Tissue
} \author{
Ayla Eren Özdemir², Arzu Şahin ${ }^{4}$ \\ ${ }^{1}$ Sakarya Üniversitesi, Tip Fakültesi, Fizyoloji Anabilim Dal. Sakarya/Türkiye. \\ ${ }^{2}$ Sakarya Üniversitesi, Sağlık Hizmetleri Meslek Yüksekokulu. Sakarya/Türkiye. \\ ${ }^{3}$ İstanbul Universitesi, Cerrahpaşa Tip Fakültesi, Biyofizik Anabilim Dalı. İstanbul/Türkiye. \\ ${ }^{4}$ Uşak Üniversitesi, Tip Fakültesi, Fizyoloji Anabilim Dalı. Uş̧ak/Türkiye.

Yazışma Adresi / Correspondence:
Songül Doğanay
Sakarya Üniversitesi Tip Fakültesi, Fizyoloji Anabilim Dalı. Sakarya/Türkiye
T: +90 $5309523295 \quad$ E-mail : songuldoganay@sakarya.edu.tr
Geliş Tarihi / Received : 29.08.2020 Kabul Tarihi / Accepted : 10.10.2020
Orcid :
Songül Doğanay: Https://Orcid.Org/0000-0002-1730-1331
Şeyma Trabzon: Https://Orcid.Org/0000-0001-9030-7804
Nurten Bahtiyar: Https://Orcid.Org/0000-0003-2420-8415
Derya Güzel Erdoğan: Https://Orcid.Org/0000-0002-7618-5043
Ayla Eren Özdemir: Https://Orcid.Org/0000-0002-0555-7049
Arzu Şahin: https://orcid.org/0000-0002-8789-4582
( Sakarya Tip Dergisi / Sakarya Med J 2020, 10(4):608-614) Dol: 10.31832/smj. 787622

Songül Doğanay ${ }^{1}$, Şeyma Trabzon², Nurten Bahtiyar ${ }^{3}$, Derya Güzel Erdoğan',

$\ddot{O} z_{z}$

Amaç Bu çalş̧mada Streptozotosin (STZ) ile deneysel tip 1 diyabet olușturulan sıçanların kan ve karaciğer dokularnnda oluşan oksidatif hasara karṣı melatonin takviyesinin koruyucu etkisinin araștırılması amaçlandı.

Gereç ve Krrk adet yetiskkin Spraque Dawley erkek sıçan; grup 1- kontrol grubu, grup 2-diyabet olușturulan grup, grup 3- melatonin takviye grubu ve grup 4- diyabet ve melatonin Yöntem takviye grubu olmak üzere dört gruba ayrıldı. Sıçanlara tek doz $60 \mathrm{mg} / \mathrm{kg}$ STZ İntraperitoneal (i.p.) olarak uygulanması ile diyabet olușturuldu. Melatonin takviyesi ise $10 \mathrm{mg} / \mathrm{kg} / \mathrm{gün}$ dozunda subkutan olarak (s.c.) 6 hafta boyunca uygulandı. Deney sonunda alınan karaciğer ve serum örneklerinde; glutatyon (GSH), katalaz (CAT) ve malondialdehit (MDA) düzeyleri spektrofotometrik yöntem kullannlarak ölçüldü.

Bulgular Çalıșma sonuçları diyabetik hayvanların serum ve karaciğer dokularında MDA düzeylerinin arttığını gösterdi. Melatonin uygulamasının her iki dokuda da MDA düzeylerini azaltıp, GSH ve CAT düzeylerini artırdığı veya düşmesini engelleyerek kararlı bir şekilde kalmasını sağladığı görüldü $(\mathrm{p}<0,05)$.

Sonuç Bu çalıșma sonuçları, diyabetin komplikasyonlarının temel nedenlerinden birinin de oksidatif stres olduğunu vurgulayan ve kabul eden ortak görüşle uyumludur. Sonuçlarımız melatoninin diyabette artan oksidatif stres üzerinde iyileștirici etkisinin bulunduğunu ve melatoninin terapötik bir ajan olarak kullanılabileceğini göstermektedir.

Anahtar Glutatyon; katalaz; melatonin; oksidatif stres; tip 1 diyabet.

Kelimeler

Abstract

Objective In this study, it was aimed to investigate the antioxidant protective effect of melatonin supplementation against oxidative damage in blood and liver tissues of rats with experimental type 1 diabetes with Streptozotocin (STZ).

Materials Forty adult Spraque Dawley male rats; Group 1-Control group, Group 2-diabetes group, Group 3- melatonin supplement group and Group 4- diabetes and melatonin supplement group were and methods divided into four groups. Diabetes was induced in rats by administering a single dose of $60 \mathrm{mg} / \mathrm{kg} \mathrm{STZ} \mathrm{intraperitoneally.} \mathrm{Melatonin} \mathrm{supplementation} \mathrm{was} \mathrm{administered} \mathrm{at} \mathrm{a} \mathrm{dose} \mathrm{of} 10 \mathrm{mg} /$ $\mathrm{kg} /$ day subcutaneously for 6 weeks. Glutathione (GSH), catalase (CAT) and malondialdehyde (MDA) levels were measured spectrophotometrically in the liver and serum samples taken at the end of the experiment.

Results The results of the study showed that MDA levels increased in the serum and liver tissues of diabetic animals. It was observed that melatonin administration decreased MDA levels in both tissues, increased GSH and CAT levels or kept them stable by preventing it from falling $(p<0.05)$.

Conclusion The results of this study are consistent with the consensus that emphasizes and accepts that one of the main causes of complications of diabetes is oxidative stress. Our results show that melatonin has an ameliorating effect on increased oxidative stress in diabetes and melatonin can be used as a therapeutic agent.

Keywords Catalase; gutathione; melatonin; oxidative stress; type 1 Diabetes. 


\section{GIIRIŞ}

Diyabetes Mellitus (DM), dünya genelinde en yaygın görülen kronik hastalık olarak kabul edilmektedir. Serbest oksijen radikalleri (SOR), DM'de ve diğer kronik hastalıklarda neden olduğu patolojik etkileri uzun ylllardan beri tartışılmaktadır. ${ }^{1}$ Diyabetin her iki türünde de SOR üretiminin arttığına ve diyabetin başlangıcının oksidatif stresle yakından ilişkili olduğuna dair çok sayıda deneysel ve klinik çalışma vardır. Bu çalışmalarda, hipergliseminin enzimatik olmayan glikasyon, enerji metabolizmasındaki değişikliklerden kaynaklanan metabolik stres, sorbitol yol aktivitesi ve hipoksi sonucunda oluşan doku hasarının serbest radikal üretimini arttırdığı ve antioksidan savunma sisteminde değişikliğe yol açtığ belirtilmektedir. ${ }^{2-4}$

Oksidatif stres, SOR veya reaktif azot türlerinin (RAT) artmasından kaynaklanmaktadır. Artan SOR ürünleri arasinda süperoksit, ve hidroksil radikali, hidrojen peroksit ve singlet oksijen türleri yer alır. ${ }^{5}$ Diyabette olası oksidatif stres kaynakları glikozun oto-oksidasyonuna, redoks dengelerinde kaymalara, glutatyon (GSH) ve E vitamini gibi düşük moleküler ağıllıklı antioksidanların dokularda konsantrasyonlarının azalmasına, süperoksit dismutaz (SOD) ve katalaz gibi hücre içi antioksidan enzimlerin aktivitelerinin bozulmasina neden olmaktadırlar. ${ }^{1}$ Hipergliseminin neden olduğu SOR üretimi, yüksek glikoz ve diyabetik komplikasyonların gelişimi için önemli olan diğer metabolik anormalliklere nedensel olarak bağlı olmasına rağmen oksidatif stresin diyabetik komplikasyonların gelişimine nasıl katkıda bulunduğu tam olarak henüz aydınlatılamamıştır. ${ }^{6}$

Dünya genelinde antioksidanların koruyucu ajan olarak kullanıldığı çeşitli deneysel hayvan çalışmaları yapılmıştır ve yapilmaya da devam edilmektedir. Bu çalışmalar içerisinde DM'de çeşitli antioksidanlar kullanılarak yapılan araştırmalar önemli oranda yer almaktadır. ${ }^{7}$ Yapılan deneysel diyabetik hayvan çalışmalarının sonuçları antioksidan ajanların kullanımının DM'de oluşan oksidatif hasar ve DM'nin koplikasyonlarını önlemede yararlı etkileri olduğunu göstermiştir. ${ }^{6}$ Özellikle son yıllarda melatoninin (MEL), antioksidan etkilerinin araştırıldığı çok sayıda araştırma mevcuttur. MEL epifiz bezinden salgılanan, hem suda hem de yağda çözünme özelliğiyle hücrelere kolaylıkla girebilen güçlü bir antioksidandır. ${ }^{8}$ MEL'in mitekondriyal homeostazinin düzenlenmesinde kritik role sahip olduğu gösterilmiştir. MEL, SOD, glutatyon peroksidaz (GSH-Px) veCAT dahil olmak üzere birçok antioksidan enzimin sentezini uyarı SOR'u azaltarak, lipit peroksidasyonunu ve DNA hasarını inhibe etmektedir. ${ }^{9}$ Menopozdan sonra melatonin takviyesinin insülin duyarlılığını ve glikoz toleransını azalttığı gösterilmiştir. MEL karaciğerde karbonhidrat kullanımını arttırarak hepatik lipolizi azaltmaktadır. Uzun süreli MEL tedavisinin kanda insülin, leptin, trigliseritler, yüksek yoğunluklu lipoprotein (HDL) ve toplam kolesterol seviyelerinin artmasına neden olduğu bildirilmiştir. ${ }^{10}$ Bizde litaratürdeki bu bilgiler doğrultusunda çalışmamızda STZ ile deneysel Tip 1diyabet oluşturulmuş sıçanlarda melatonin takviyesinin kan ve karaciğer dokularında antioksidan koruyucu etkilerini araştırmayı amaçladık. Bu amaçla oksidatif stres belirteci olarak MDA düzeyi ve antioksidan enzimler olarak CAT ve GSH düzeylerini araştırdık.

\section{GEREÇ ve YÖNTEM}

\section{Deney Tasarımı ve Uygulanması}

Çalışmada ortalama 250-300 gram ağırlığında 10-12 haftalık 40 adet Spraque- Dawley erkek sıçan kullanıldı. Hayvanlar 6 hafta boyunca, standart laboratuvar koşullarında (12/12 saat aydınlık/karanlık 1şık döngüsünde, sıcaklı̆ğ $22^{\circ} \mathrm{C}$, nem oranı $\% 50-60$ ) tel kafeslerde tutuldu. Tüm s1çanlar standart pellet yem ve musluk suyu ile beslendi. S1çanlar her grupta 10 hayvan olacak şekilde rastgele 4 gruba bölündü:

Grup 1: Kontrol grubu olarak belirlendi. Bu gruptaki hayvanlar normal diyetle beslendi ve her hangi bir işlem yapilmadi.

Grup 2: Bu gruptaki sıçanlara $60 \mathrm{mg} / \mathrm{kg}$ dozunda tek doz STZ intraperitoneal (i.p.) enjeksiyon yapilarak diyabetes mellitus oluşturuldu. 
Grup 3: Melatonin takviyesi yapılan grup. Bu gruptaki s1çanlara deney başlangıcından itibaren 6 hafta boyunca 10 $\mathrm{mg} / \mathrm{kg} /$ gün dozunda melatonin subkutan (sc.) enjeksiyon uyguland.

Grup 4: Diyabet ve Melatonin takviyesi yapılan grup. 60 $\mathrm{mg} / \mathrm{kg}$ dozunda STZ i.p. enjeksiyon uygulandıktan sonra diyabetes mellitus oluşturuldu. Ayrıca bu gruptaki hayvanlara 6 hafta boyunca her gün $10 \mathrm{mg} / \mathrm{kg}$ dozunda melatonin sc. enjeksiyon uyguland.

6 haftalık deney süresince tüm gruplara normal diyet ve musluk suyu verildi. Deney hayvanlarında diyabet oluşturmak için hayvanlar 1 gün öncesinden (12 saat) aç b1rakıldı. Ertesi gün açlık kan şekeri ve ağırlıkları ölçüldü. Daha sonra $60 \mathrm{mg} / \mathrm{kg}$ dozunda STZ (Cayman Chemical item no, 13104, USA) pH 7,2 PBS içinde tek doz i.p. enjeksiyon uygulandı. STZ uygulamasından 2 gün sonra açlık kan şekeri düzeyleri kuyruk veninden alınan kan örnekleri ile ölçüldü. Kan şekeri düzeyi $250 \mathrm{mg} / \mathrm{dL}$ üzerinde olan sıçanlar diyabetik kabul edildi ve deneye alındı. STZ enjeksiyonundan sonra tedaviye üçüncü gün başlandı ve bu tedavinin ilk günü olarak kabul edildi. Melatonin takviyesi (Cayman Chemical East ellsworth rd. İtem no; 14427, USA) diyabet oluşturulduktan sonra 6 hafta boyunca günlük \%10 etanol içeren \%0,9 $\mathrm{NaCl}$ çözeltisi içinde hazırlandı ve $10 \mathrm{mg} / \mathrm{kg}$ dozunda sc. enjeksiyon ile uygulandı. Deney protokolleri Sakarya Üniversitesi Hayvan Bakım ve Kullanım Etik Kurulu'ndan onay alındıktan (21.02.2018/01) sonra Sakarya Üniversitesi Hayvan Laboratuvarı'nda uluslararası yönergelere uygun olarak gerçekleştirildi.

Deney sonlandırılmadan 12 saat önce aç bırakılan sıçanlar 65 mg / kg (i.p.) ketamin ve 7 mg / kg ksilazin (i.p.) enjeksiyonu ile genel anestezi altında yüksek doz kan alımı ile sakrifiye edildikten sonra doku örnekleri alındı ve laboratuvar analizleri yapilıncaya kadar $-20^{\circ}$ C'de saklandı.

\section{Doku Homojenatlarının Hazırlanması}

Dokular tartıldıktan sonra \%0,9 NaCl çözeltisi ile yıkandı. Yıkama işleminin ardından santrifüj edildi $\left(+4{ }^{\circ} \mathrm{C}, 3000\right.$
RPM, $10 \mathrm{dk}$ ). Sonra soğuk \%1,15 $\mathrm{KCl}, 0,01 \mathrm{M}$ sodyum potasyum fosfat $(\mathrm{pH}=7.4)$ çözeltisinde homojenize edildi. $\% 10$ 'luk doku homojenatları hazırlandı. Bu homojenatlar 10.000 RPM'de $20 \mathrm{dk},+4{ }^{\circ} \mathrm{C}^{\prime}$ de santrifüj edildi. Süpernatan alınıp dokularda MDA, GSH ve CAT parametrelerinin belirlenmesinde kullanıldı. Lowry yöntemi kullanılarak örneklere ait protein ölçümü yapıldı. ${ }^{11}$

\section{MDA Ölçümü}

Doku homojenatlarında MDA tayini Buege ve Aust'un yöntemi kullanılarak lipid peroksidasyon ürünlerinden olan MDA'nın tiyobarbütirik asit (TBA) ile reaksiyon vererek $532 \mathrm{~nm}$ dalga boyunda ölçülebilen renkli bir bileşik vermesi esasına bağlı olarak gerçekleştirildi. Sonuçlar nM/ mg protein olarak verildi. ${ }^{12}$

\section{GSH Ölçümü}

Doku homojenatlarında GSH tayini için 412 nm'de maksimum absorbans gösteren TNB'yi oluşturmak için 5' 5'-Dithiobis 2-nitrobenzoik asit (DTNB) ve GSH arasındaki reaksiyon kullanıldı. Sonuçlar $\mu \mathrm{M} / \mathrm{mg}$ protein olarak verildi. $^{13}$

\section{CAT Ölçümü}

Doku homojenatlarında CAT aktivitesi, H2O2'nin KAT tarafından parçalanması temeline dayanan spektrofotometrik yöntem ile belirlendi. $240 \mathrm{~nm}$ dalga boyunda CAT-peroksit reaksiyonu sonucunda zamanla azalan absorbans farkı kullanılarak hesaplama yapıldı. Sonuçlar U/ mg protein olarak verildi. ${ }^{14}$

\section{İstatistiksel Değerlendirme}

İstatistiksel analizler SPSS 22.0 paket programı (SPSS Inc. ve Lead Tech. Inc. Chicago. ABD) kullanılarak yapıldı. Sayısal veriler ortalama \pm standart sapma (SD) olarak verildi. Verilerin normal dağılımı için Kolmogrov Smirnov testi kullanıldı. İkiden fazla değişkenin karşılaştırılmasında one-way ANOVA ve Kruskal Wallis testi kullanıldı. Grup içi anlamlılıklar varyansların homojen olduğu değişkenlerde TUKEY HSD, homojen olmayan değişkenlerde Tam- 
hane's T2 testi uygulandı. Anlamlılık sinırı $\mathrm{P}<0,05$ olarak kabul edildi.

\section{BULGULAR}

\section{Vücut Ağırlığı ve Kan Şekeri Seviyeleri}

Yapılan bu deneysel çalışma sonucunda çalışmaya başlamadan önce tüm gruplar arasında vücut ağırlığı (A1) yönünden anlamlı bir farklılık yoktu ( $>>0,05)$. Altı haftalık deney sonunda diyabetik sıçanların vücut ağırlıkları Grup 1 ve Grup 3’ten daha düşüktü. Gruplar arası vücut ağırlığ1 (A2) karşılaştırması yapıldı ğında Grup 1 ile Grup 3 ve Grup 4 arasında; Grup 3 ile Grup 4 arasında istatistiksel olarak önemli farklılık tespit edildi (p değeri sırasıyla; $\mathrm{p}=0,015 ; \mathrm{p}=0,019 ; \mathrm{p}=0,000$ ), (Tablo 1).

\begin{tabular}{|c|c|c|c|c|}
\hline \multirow{2}{*}{$\begin{array}{l}\text { Grup } \\
\text { (Her } \\
\text { grup } \\
n=10)\end{array}$} & \multicolumn{2}{|c|}{$\begin{array}{c}\text { Vücut ağırlığı }(g) \\
\text { ort } \pm \text { SD }\end{array}$} & \multicolumn{2}{|c|}{$\begin{array}{c}\text { Kan şekeri }(\mathrm{mg} / \mathrm{dL}) \\
\text { ort } \pm \mathrm{SD}\end{array}$} \\
\hline & A1 & A2 & KŞ1 & KŞ2 \\
\hline $\begin{array}{l}\text { Grup } \\
1\end{array}$ & $267,40 \pm 21,96$ & $317,20 \pm 26,74$ & $93,20 \pm 1,031$ & $91 \pm 5,22$ \\
\hline $\begin{array}{l}\text { Grup } \\
2\end{array}$ & $266,10 \pm 26,89$ & $265,20 \pm 38,43$ & $97,20 \pm 3,25$ & $497,90 \pm 48,33$ \\
\hline $\begin{array}{l}\text { Grup } \\
3\end{array}$ & $262,80 \pm 21,4039$ & $346,80 \pm 24,21$ & $94,60 \pm 3,74$ & $104,10 \pm 5,86$ \\
\hline $\begin{array}{l}\text { Grup } \\
4\end{array}$ & $266,00 \pm 22,88$ & $266,80 \pm 50,24$ & $96,60 \pm 3,27$ & $446,70 \pm 153,83$ \\
\hline $\begin{array}{l}\mathbf{P} \\
\text { değeri }\end{array}$ & 0,965 & $\begin{array}{l}0,015(\mathbf{1}-3) \\
0,019(\mathbf{1}-4) \\
0,000(3-4)\end{array}$ & 0,114 & $\begin{array}{c}0,000(1-2, \\
3,4) \\
0,000(2-3) \\
0,000(3-4)\end{array}$ \\
\hline
\end{tabular}

Grup 1: Kontrol, Grup 2: Diyabet, Grup 3: Melatonin takviye grubu, Grup 4: Diyabet+Melatonin takviye grubu, A1: Başlangıçta vücut ağırlıkları A2: Dekapitasyon öncesi vücut ağırlıkları, KŞ1: Başlangıç kan sekeri sonuçları, KŞ2: Dekapitasyon öncesi kan şekeri sonuçları. Anlamlılık sınırı $\mathrm{P}<0,05$ olarak kabul edilmiştir. SD; Standart Sapma, ort; Ortalama

Deney modeli oluşumu öncesinde tüm gruplara ait başlangıç kan şekeri(KŞ1) değerleri arasında istatistiksel bir fark bulunmadı ( $p>0,05)$. Diyabet modeli oluşturulduktan sonra deney sürecinin tamamlanıp dekapitasyon öncesi gruplara ait ortalama kan şekeri değerleri Tablo 1'de gösterilmiştir. KŞ2 sonuçları incelendiğinde; Grup 1 ile Grup 2, Grup 3 ve Grup 4 arasında istatistiksel olarak anlamlı farklılık olduğu, Grup 1'in ortalama değerinin bu gruplardan oldukça düşük olduğu tespit edildi $(\mathrm{p}=0,000)$. Ayrıca Grup 2 'nin ortalama kan şekeri değerinin Grup 1 ve Grup 3'ün ortalama kan şekeri değerinden, yine Grup 4'ün ortalamasının da Grup 3'ün ortalama değerlerinden istatistiksel olarak anlamlı derece yüksek olduğu belirlendi ( $\mathrm{p}=0,000$; $\mathrm{p}=0,000)$. Grup 2'nin KŞ2 değerinin ise Grup 4'ün ortalama kan şekeri değerinden oldukça yüksek olduğu gözlendi ancak bu farklılık istatistiksel olarak anlamlı değildi ( $\mathrm{p}>0,05)$, (Tablo 1).

\section{Biyokimyasal Parametreler}

Karaciğer dokusu MDA, GSH ve CAT düzeyleri Tablo 2 de gösterilmiştir. MDA seviyelerine bakıldığında; Diyabet+Melatonin takviye grubu olan Grup 4'te en düşük düzeyde, diyabet grubu olan Grup 2'de Grup 3 ve Grup 4 ile kiyaslandığında istatistiksel olarak anlamlı düzeyde yüksekti (sırasiyla; $\mathrm{p}=0,000, \mathrm{p}=0,010$ ). CAT düzeyleri Grup 1'de Grup 3 ve Grup 4'e göre istatistiksel açıdan önemli derecede yüksekti (sırası ile $p=0,000, p=0,002, p=0,005$ ). GSH seviyeleri ise diyabet grubunda belirgin düzeyde düşüktü. Ancak melatonin uygulanan gruplar olan Grup 3 ve Grup 4'te Grup 1 ve Grup 2'den daha yüksekti. Bu sonuçlarda melatonin uygulamasının GSH düzeylerinde artışa neden olduğunu, fakat bu artışın istatistiksel yönden anlamlı olmadığ

\begin{tabular}{|c|c|c|c|}
\hline $\begin{array}{l}\text { Grup } \\
\text { (Her grup n= } \\
10)\end{array}$ & $\begin{array}{l}\text { MDA }(\mathrm{nM} / \mathrm{mg}) \\
\quad \text { ort } \pm \mathrm{SD}\end{array}$ & $\begin{array}{c}\mathrm{GSH}(\mu \mathrm{M} / \mathrm{mg} \\
\text { Protein }) \\
\text { ort } \pm \mathrm{SD}\end{array}$ & $\begin{array}{c}\text { CAT (U/mg } \\
\text { Protein) } \\
\text { ort } \pm \text { SD }\end{array}$ \\
\hline Grup 1 & $0,322 \pm 0,114$ & $0,793 \pm 0,155$ & $27,499 \pm 8,127$ \\
\hline Grup 2 & $0,455 \pm 0,156$ & $0,751 \pm 0,153$ & $10,553 \pm 3,648$ \\
\hline Grup 3 & $0,404 \pm 0,127$ & $0,807 \pm 0,270$ & $12,693 \pm 6,813$ \\
\hline Grup 4 & $0,298 \pm 0,075$ & $0,813 \pm 0,335$ & $15,179 \pm 3,713$ \\
\hline$P$ değeri & $\begin{array}{l}0,023(1-2) \\
0,000(2-3) \\
0,010(2-4) \\
0,036(3-4)\end{array}$ & $\mathrm{p}>0,05$ & $\begin{array}{l}0,000(1-2) \\
0,002(1-3) \\
0,005(1-4)\end{array}$ \\
\hline
\end{tabular}

Grup 1: Kontrol, Grup 2: Diyabet, Grup 3: Melatonin takviye grubu, Grup 4: Diyabet+Melatonin takviye grubu, MDA: Malondialdehit; GSH: Glutatyon; CAT: Katalaz; SD; Standart Sapma. Anlamlılık sınırı $\mathrm{P}<0,05$ olarak kabul edilmiştir. Sonuçlar ortalama \pm SD olarak verilmiştir. 
Çalışma sonucumuzda; serum MDA seviyelerinin diyabet grubunda diğer gruplara oranla istatistiksel olarak anlamlı düzeyde arttığı ve melatonin uygulamasının diyabette oksidatif stresi azalttığ belirlendi (sırasıyla; $\mathrm{p}=0,000, \mathrm{p}=0,000$, $\mathrm{p}=0,002)$. CAT düzeyleri incelendiğinde; melatonin uygulaması sonucunda Grup 2’nin ortalama CAT düzeyi Grup 1 ve Grup 3'e nazaran oldukça düşüktü. Gruplara arası karşılaştırma yapıldığında bu düşüş istatistiksel açıdan oldukça anlamlıydı (sırasıyla p=0,028, p=0,009), (Tablo 3).

\begin{tabular}{|c|c|c|c|}
\hline \multicolumn{4}{|c|}{$\begin{array}{l}\text { Tablo 3: Deney grupları serum biyokimyasal parametrelerin } \\
\text { karşılaştırılması. }\end{array}$} \\
\hline $\begin{array}{l}\text { Grup } \\
\text { (Her grup } n= \\
10)\end{array}$ & $\begin{array}{l}\text { MDA (nM/mg) } \\
\quad \text { ort } \pm \text { SD }\end{array}$ & $\begin{array}{l}\mathrm{GSH}(\mu \mathrm{M} / \mathrm{mg} \\
\text { Protein }) \\
\text { ort } \pm \mathrm{SD}\end{array}$ & $\begin{array}{l}\text { CAT }(\mathrm{U} / \mathrm{mg} \\
\text { Protein) } \\
\text { ort } \pm \mathrm{SD}\end{array}$ \\
\hline Grup 1 & $18,673 \pm 2,796$ & $40,155 \pm 4,831$ & $162,833 \pm 37,962$ \\
\hline Grup 2 & $24,682 \pm 2,376$ & $29,599 \pm 2,862$ & $115,550 \pm 35,953$ \\
\hline Grup 3 & $18,761 \pm 2,036$ & $37,517 \pm 9,692$ & $170,281 \pm 36,731$ \\
\hline Grup 4 & $20,463 \pm 2,727$ & $29,885 \pm 5,251$ & $157,735 \pm 33,421$ \\
\hline$P$ değeri & $\begin{array}{l}0,000(1-2) \\
0,000(2-3) \\
0,002(2-4)\end{array}$ & $\begin{array}{l}0,003(1-2) \\
0,004(1-4) \\
0,042(3-4)\end{array}$ & $\begin{array}{l}0,028(1-2) \\
0,009(2-3)\end{array}$ \\
\hline \multicolumn{4}{|c|}{$\begin{array}{l}\text { Grup 1: Kontrol, Grup 2: Diyabet, Grup 3: Melatonin takviye grubu, } \\
\text { Grup 4: Diyabet+Melatonin takviye grubu, MDA: Malondialdehit; } \\
\text { GSH: Glutatyon; CAT: Katalaz; SD; Standart Sapma. Anlamlllı sinırı } \\
\text { P<0,05 olarak kabul edilmiştir. Sonuçlar ortalama } \pm \text { SD olarak verilmiştir. }\end{array}$} \\
\hline
\end{tabular}

Serum GSH düzeyleri Grup 2'de diğer gruplara kıyasla en düşük düzeydeydi. Gruplar arası karşılaştırmalar yapıldığında ise; Grup 1 GSH düzeylerinin; Grup 2 ve Grup 4'e oranla anlamlı düzeyde yüksek olduğu (sırasıyla $\mathrm{p}=0,003$, $\mathrm{p}=0,004$ ), yine Grup 4'ün ortalama GSH düzeyinin de Grup 3’ten istatistiksel açıdan anlamlı derecede yüksek olduğu belirlendi $(\mathrm{p}=0,042)$.

\section{TARTIŞMA ve SONUÇ}

Diyabette oksidatif stres, diyabet ve diyabete bağlı gelişen komplikasyonlar arasındaki ilişkilerin mekanizmalarını araştıran çalışmalar gün geçtikçe artarak devam etmektedir, Bu çalışmalarda diyabette oksidatif stresin artışı ile serbest radikal oluşumu artarken, antioksidan üretiminin ise azaldığı gösterilmiştir. ${ }^{15,16}$

Bizim çalışmamızda; deney başlangıcında tüm gruplarda vücut ağırlıkları aynı sevilerde iken altı haftalık deney sonunda kontrol ve melatonin gruplarında kilo artışının, diyabetik gruplarda ise kilo kaybının gerçekleştiği görüldü. Bazı deneysel diyabet çalışmalarında ise diyabet grubunda kilo kaybının olduğu ve bu kayıbında genellikle yüksek kan glikoz seviyeleri nedeni ile doku proteinlerinde aşırı yıkıma bağlı olarak görüldüğü bildirilmiştir. Ayrıca bu düşüşün daha sonra yavaşladığı da belirtilmiştir. ${ }^{17}$

Diyabet oluşturulan sıçanların kan şekeri düzeyleri STZ enjeksiyonunu takiben 3 gün sonra $250 \mathrm{mg} / \mathrm{dL}$ düzeyinde belirlendi. Çalışmamızda kan glikoz konsantrasyanlarının Grup 4'de ( Diyabet + melatonin) Grup 2'ye oranla yaklaşık 51 birim azaldığ görüldü ancak aradaki bu farklılık istatistiksel olarak anlamlı değildi. Bizim sonuçlarımız literatürdeki bazı çalışmalarla da desteklenmektedir. ${ }^{17}$ Çalışmamızın sonuçlarının aksine; melatonin farklı dozlarda uygulandığ 8 haftalık bir çalışmada ise kan glikoz düzeylerinde anlamlı düşüşün olduğu bildirilmiştir. ${ }^{18}$ Yine bir başka çalışmada da STZ enjeksiyonundan (140 mg/kg intravenöz) $30 \mathrm{dk}$ önce melatonin (100 mg/kg) uygulanmasının diyabet oluşumunu engellediği rapor edilmiştir. ${ }^{19}$

Oksidatif stres durumlarında dokularda MDA ve TOS seviyelerinde artış görülür. ${ }^{20}$ Literatürdeki çalışmalar incelendiğinde STZ ile deneysel olarak diyabet oluşturulan sıçanlarda ve tip 1 ve tip 2 diyabet hastalarında SOR üretiminin hızlandığı belirlenmiştir. Oksidatif stres artışı ile oluşan MDA düzeylerinde artışla birlikte glutatyon homeostazisinde bozulmaların olduğu saptanmıştır. ${ }^{21,22}$ Konu ile ilgili bilimsel çalışmalar; diyabet ve diyabet komplikasyonlarının SOR’un ilişkisinde antioksidan savunma sistemini değiştirebileceğini, vurgulamaktadır. Literatürde çok sayıda deneysel diyabet çalışmasında antioksidan ajanların kullanımının birçok dokuda oksidatif hasarı azalttığı ve DM komplikasyonlarına karşı dokuları koruduğu açıkça gösterilmiştir. ${ }^{23}$ Bizim çalışmamızda STZ ile deneysel tip I diyabet oluşturulan sıçanların serum ve karaciğer dokularında oluşacak oksidatif hasara karşı güçlü antioksidan ajan olan melatoninin olası etkileri araştırıldı. 
Sunulan bu çalışmada elde edilen sonuçlara göre DM'nin serum ve karaciğer dokularında MDA seviyelerinde artma, buna karşın oksidatif strese karşı savunma hattında önemli görevleri olan endojen antioksidan enzimlerden GSH ve CAT düzeylerinde azalmaya neden olduğu gözlendi. Melatonin takviyesi sonrasında bu grupların karaciğer dokusunda MDA düzeylerinde azalmaların olduğu, GSH düzeylerinin düşmesinin engellendiği ve CAT düzeylerinde önemli oranda artışlar olduğu gözlendi. Literatürde diyabette oksidatif stres durumunda MDA seviyelerinin arttığını gösteren ve bizim sonuçlarımızı destekleyen çok sayıda çalışma bulunmaktadır. ${ }^{24-26}$

Çeşitli çalışmalar; DM'nin karaciğer dokusunda hücresel dejenerasyon, fibrozis ve inflamasyon gibi histopatolojik değişiklikleri de içeren komplikasyonlara yol açtığını ve diyabetli hastalar arasında siroza bağlı ölüm oranının kardiyovasküler hastalıklardan daha yüksek olduğunu göstermektedir. ${ }^{27}$ Ayrıca kronik hiperglisemi sonucunda artan SOR ve inflamatuar cevap, DM sonucunda karaciğerde oluşan değişiklikler den sorumlu tutulmaktadır. ${ }^{28}$ Güçlü bir radikal temizleyicisi olan melatonin, STZ’nin neden olduğu DM’nin yanı sıra MDA düzeyini azaltarak, pankreası ve diğer dokuları olası oksidatif hasara karşı koruyucu etki göstermektedir. Elbe ve ark. çalışmalarında DM ile karaciğer dokusunda MDA düzeylerinin arttığını, GSH düzeylerinin azaldığını ve bu değişikliklerin melatonin takviyesi ile kontrol düzeylerine geldiğini saptamışlardır. ${ }^{29}$ Bir başka çalışmada melatoninle birlikte $C$ ve $E$ vitamini verilen diyabetik ratlarda plazma glukoz ve MDA düzeylerinde azalma, hematolojik ve biyokimyasal parametrelerle antioksidan düzeylerinin normale döndüğü ifade edilmiştir. ${ }^{30}$ Melatoninin Beta hücrelerini koruyarak, insülin sekresyonunun uyarımını arttırma gibi bir etkisi mevcuttur. Yüksek lipofilik özelliği ve küçük moleküler yapıda olmasından dolayı hücre membranından kolayca geçebilen melatoninin oksidatif strese maruz birakılan eritrositlerin içine girerek hücreleri koruduğu bildirilmiştir. ${ }^{31}$ Şekeroğlu ve ark. farelerde DM oluşturarak melatonin tedavisi uyguladıkları çalışmalarında, kontrol grubuna kıyasla diyabetik farelerin eritrositlerinde MDA seviyelerinin arttığını, melatonin tedavisinin hücrelerde GSH ve GSH-Px aktivitesini artırdığını bildirmişlerdir. ${ }^{32}$

Sonuç olarak literatürdeki diğer çalışmalarda bildirildiği gibi yapmış olduğumuz bu çalışmada da diyabette kan glukoz düzeylerinin uzun süre yüksek seviyelerde seyretmesinin dokularda oksidatif stresi artırabileceği gösterilmiştir. Çalışmamızda MDA düzeylerinin DM durumunda artması oksidatif hasarın oluştuğunu, melatonin takviyesi sonrasında antioksidan enzimlerde artışın olması ise melatoninin oksidatif hasara karşı MDA düzeylerini düşürerek dokularda endojen antioksidan enzim savunma mekanizmalarının başlamasını tetiklediğini göstermektedir. DM’de oluşabilen oksidatif stresin yeni terapötik yaklaşımlara yol açabileceği ve tedavide ilaçlara ek olarak antioksidan ajanların kullanımının bozulan oksidan-antioksidan dengenin ve glukoz metabolizmasının düzeltilmesinde önemli etkiler oluşturabileceği gösterilmiştir. Bu antioksidan ajanların en önemlilerinden biri olan melatonininle ilgili deneysel çalışmaların yanı sıra DM'li hastalarda kapsamlı ve kontrollü klinik çalışmalar yapılarak etkilerinin değerlendirilmesi bilimsel acıdan önemli katkılar sağlayacaktır.

\section{Etik Kurul Onayı}

Bu çalışma Sakarya Üniversitesi Tıp Fakültesi Hayvan Bakım ve Kullanım Etik Kurulu'ndan (Karar No: 21.02.2018/01) onay alındıktan sonra Sakarya Üniversitesi Hayvan Laboratuvarı'nda uluslararası yönergelere uygun olarak gerçekleştirildi.

\section{Çıkar Çatışması}

Herhangi bir çıkar çatışmasının olmadığı yazarlar tarafından onaylanmıştır.

\section{Finansal Destek}

Bu çalışma Sakarya Üniversitesi BAP birimi tarafından 2018-08-06-001 proje numarası (hızlı destek) ile desteklenmiştir. 
Sakarya Tip Dergisi 2020;10(4):608-614

DOĞANAY ve Ark., Tip 1 Diyabette Melatoninin Antioksidan Aktivitesi

\section{Kaynaklar}

1. Matough FA, Budin SB, Hamid ZA, Alwahaibi N, Mohamed J. The role of oxidative stress and antioxidants in diabetic complications. Sultan Qaboos University Medical Journal 2012;12(1):1-5

2. El Faramawy SM, Rizk RA. Spectrophotometric studies on antioxidants-doped liposomes. J Am Sci 2011;7(7):363-369.

3. Madawala SR, Andersson RE, Jastrebova JA, Almeida M, Dutta PC. Novel Conjugates of 1,3-Diacylglycerol and Lipoic Acid: Synthesis, DPPH Assay, and RP-LC-MS-APCI Analysis. J Lipids 2011:419809. doi: 10.1155/2011/419809

4. Niedowicz DM, Daleke DL. The role of oxidative stress in diabetic complications. Cell Biochem Biophys, 2005. 43(2):289-330.

5. Rosen P, Nawroth P, King G, Moller W, Tritschler HJ, Packer L. The role of oxidative stress in the onset and progression of diabetes and its complications: a summary of a Congress Series sponsored by UNESCO-MCBN, the American Diabetes Association and the German Diabetes Society. Diabetes Metab Res Rev 2001;7(3):189-212. doi: 10.1002/dmrr.196

6. Kowluru RA, and Chan PS, Oxidative stress and diabetic retinopathy. Exp Diabetes Res 2007;43603. doi: 10.1155/2007/43603

7. Johansen JS, Harris AK, Rychly DJ, Ergul A. Oxidative stress and the use of antioxidants in diabetes: linking basic science to clinical practice. Cardiovasc Diabetol 2005;29;(4):5. doi: 10.1186/1475-2840-4-5

8. Sharafati-Chaleshtori R, Shirzad H, Rafieian-Kopaei M, Soltani A. Melatonin and human mitochondrial diseases. J Res Med Sci 2017;22:2. doi: 10.4103/1735-1995.199092

9. Acuna Castroviejo D, Lopez LC, Escames, López A, Garcia AJ, Reiter JR. Melatonin-mitochondria interplay in health and disease. Current topics in medicinal chemistry 2011;11(2):221-240

10. Anisimov VN., Effects of exogenous melatonin-a review. Toxicologic pathology, 2003. 31(6):589-603

11. Lowry OH, Rosebrough NJ, Farr AL, Randall RJ. Protein measurement with the Folin phenol reagent. Journal of biological chemistry 1951;193:265-275.

12. Buege JA, Aust SD. Microsomal lipid peroxidation. Methods in enzymology 1978;52:302310 .

13. Beutler E. Improved method for the determination of blood glutathione. J. lab. clin. Med 1963;61:882-888.

14. Beers RF, Sizer IW. A spectrophotometric method for measuring the breakdown of hydrogen peroxide by catalase. J Biol chem 1952;195(1):133-140.

15. Gray SP, Jandeleit-Dahm K. The pathobiology of diabetic vascular complications-cardiovascular and kidney disease. Journal of Molecular Medicine 2014;92(5):441-452.

16. Hamamcioglu AC. Diyabette Oksidatif Stres ve Antioksidanların Rolü. Türkiye Diyabet ve Obezite Dergisi 2017;1(1):7-13.

17. Elbe H, Vardi N, Esrefoglu M, Ates B, Yologlu S, Taskapan C. Amelioration of streptozotocin-induced diabetic nephropathy by melatonin, quercetin, and resveratrol in rats. Human o experimental toxicology 2015;34(1):100-113.

18. Sekkin S, İpek ED, Boyacıoğlu M, et al. DNA protective and antioxidative effects of melatonin in streptozotocin-induced diabetic rats. Turkish Journal of Biology 2015;39(6):932-940.

19. Bibak B, Khalili M, Rajaei Z, et al., Effects of melatonin on biochemical factors and food and water consumption in diabetic rats. Adv Biomed Res 2014;3:173. doi. 10.4103/22779175.139191
20. Andersson AK, Andler S, Melatonin protects against streptozotocin, but not interleukin-1 $\beta$ induced damage of rodent pancreatic $\beta$-cells. Journal of pineal research 2001;30(3):157-165.

21. Avci E, Akaslan ZZ, Erten H, Coskun CS. Oxidative stress and cellular immunity in pa tients with recurrent aphthous ulcers. Brazilian Journal of Medical and Biological Research 2014;47(5):355-360.

22. Öztürk AS, Ayekin İ, Özsoy ŞY, Öztğrk OH, Altuğ N, Yllmaz N. Effects of caffeic acid phenethyl ester on oxidative stress, hystopathology and some biochemical parameters in streptozotocin-induced diabetic rats/Streptozotocin ile indüklenen diyabetik stçanlarda oksidatif stres, histopatolojik ve bazı biyokimyasal parametrelere kafeik asit fenetil esterin etkileri. Turkish Journal of Biochemistry 2015;40(2):149-156.

23. Whiting PH, Kalansooriya A, Anura HI, Haddad F, Jennings PE. The relationship between chronic glycaemic control and oxidative stress in type 2 diabetes mellitus. British journal of biomedical science 2008;65(2):71-74

24. Jiménez-Osorio AS, Picazo A, González-Reyes S, Barrera-Oviedo D, Rodríguez-Arellano ME, Pedraza-Chaverri J. Nrf2 and redox status in prediabetic and diabetic patients. International journal of molecular sciences 2014;15(11):20290-20305.

25. Annadurai T, Vasanthakumar A, Geraldine $P$, Thomas $P$. Variations in erythrocyte antioxidant levels and lipid peroxidation status and in serum lipid profile parameters in relation to blood haemoglobin Alc values in individuals with type 2 diabetes mellitus. Diabetes research and clinical practice 2014;105(1):58-69.

26. Sajedianfard J, Behroozi Z, Nazifi S, Rajaian H. The effect of different oral doses of hydroalcoholic extract of silymarin on the blood oxidative stress indicators in streptozotocin induced diabetic rats. Int J Pept Res Ther 2013; 19:93-98.

27. Zhang $C, L u X$, Tan Y, et al. Diabetes-induced hepatic pathogenic damage, inflammation, oxidative stress, and insulin resistance was exacerbated in zinc deficient mouse model. PLoS One 2012;7(12):e49257.

28. Petrović A, Bogojević D, Korać A, et al., Oxidative stress-dependent contribution of HMGB1 to the interplay between apoptosis and autophagy in diabetic rat liver. Journal of physiology and biochemistry 2017;73(4):511-521.

29. Elbe H, Esrefoglu M, Vardi N, Taslidere EÇ, Ozerol E, Tanbek K. Melatonin, quercetin and resveratrol attenuates oxidative hepatocellular injury in streptozotocin-induced diabetic rats. Human \& experimental toxicology 2015;34(9):859-868.

30. Allagui MS, Feriani A, Bouoni Z, Alimi H, Murat JC, El-Feki A. Protective effects of vitamins ( $C$ and $E$ ) and melatonin co-administration on hematological and hepatic functions and oxidative stress in alloxan-induced diabetic rats. Journal of physiology and biochemistry 2014;70(3):713-723

31. Yavuz O, Cam M, Bukan N, Guven AÇ, Silan F. Protective effect of melatonin on $\beta$-cell damage in streptozotocin-induced diabetes in rats. acta histochemica 2003;105(3):261-266.

32. Șekeroğlu MR, Huyut Z, Çokluk E, Özbek H, Alp HH, The susceptibility to autoxidation of erythrocytes in diabetic mice: Effects of melatonin and pentoxifylline. Journal of biochemical and molecular toxicology 2017;31(12):e21976. 